\section{Maori Education Developments: A Maori Unionist's View}

\section{BILL HAMILTON}

Puritia te kakau o te hoe

kia tere whakamua ai te waka

o te matauranga Maori

$\mathrm{D}$ uring 1992, many hands seized the chance to paddle the Maori education waka in the primary system.

The Maori community continued to establish Kura Kaupapa Maori, immersion and bilingual programmes.

Schools increased the involvement of whanau in their activities and generally attempted to improve the quality of Maori education programmes.

The National Maori Congress, Te Whakakotahitanga o Nga Iwi o Aotearoa, completed a report that promoted the goal of establishing iwi education authorities.

Government established an inquiry into Maori education and directed officials committees to:

(a) develop a bold strategy for the protection and promotion of te reo Maori; and

(b) develop a comprehensive policy for Maori education.

A Maori Education Group to comment on the Minister of Education's "Vision for Education" was established.

Maori government officials and others attempted to co-ordinate an effective Maori voice in education through Te Roopu Whakahaere and Te Roopu Whanui.

Tino Rangatiratanga continued its work of co-ordinating, mobilising and politicising Maori in education and challenging the effectiveness of existing or proposed government education policy.
Finally, in an atmosphere of government hostility towards unions, the primary teachers' union, the New Zealand Educational Institute (NZEI) strengthened its philosophies, policies, priorities and practices by:

- establishing Miro Maori as an integral part of NZEI structures;

- giving leadership, direction and cohesion to the development of Maori education policies; and

- ensuring that Maori views are included in the activities, developments and changes in the general education system.

In putting forward a Maori unionist's view, there is recognition that during 1992:

- Maori people put a lot of energy into primary education for the purpose of improving Maori achievement, revitalizing te reo me ona tikanga Maori and strengthening Maori participation in the education of their children;

- NZEI, the primary teachers' union, gave significant support to Maori education developments; and

- there was a lot of government activity and stated commitment but their work lacked rigour, direction and coherency.

Although many hands paddled the Maori education waka, by the end of 1992, it had made only a minor advance from where it had been in 1991. The waka tended to veer in motion from side to side, backwards and forwards and swirled around in circles rather than tracking forwards towards achieving significant goals.

The Matauranga Maori waka clearly lacks strong navigational leadership, and government in particular is paddling against the tide of Maori aspirations.

\section{Government Activity}

Government and its agencies are in a state of panic over Maori education. Despite an incredible amount of activity in the state sector, very little of its work is translating into more effective Maori education programmes in primary schools. The work performed by government 
lacks coordination and direction. It is not being completed, people do not know what is happening and government activity is driven by fiscal constraints rather than educational needs.

\section{Kura Kaupapa Maori}

Government policy supports the expansion of Kura Kaupapa Maori either through redesignation of existing schools as Kura Kaupapa Maori or the establishment of new kura.

However government practices inhibit the growth of these Maori education initiatives.

The need to meet specific te reo or educational objectives has ceased to be a requirement for redesignation. Instead Boards of Trustees are required to confirm on their application form a signed statement to the Minister of Education that:

1. there will be no supernumerary positions created as a result of this school's designation as a kura kaupapa Maori;

2. there will be no additional costs to Vote:Education;

3. the local community is fully supportive of the board's application to have this school designated as a kura kaupapa Maori.

Clearly, meeting financial objectives (fiscal neutrality) is of greater concern to government than meeting educational objectives.

\section{Bold strategy}

In December 1991 the Ministers of Maori Affairs and Education directed officials to prepare a:

bold strategy paper which would advance kura kaupapa Maori and total immersion language initiatives, and which would outline options for a retargeting of Maori education funding, achieving maximum language and education cost benefits.

The critical goal was "the survival of te reo Maori". Draft 5 of the paper outlines three strategies.
Strategy One proposed to re-target existing funding by changing Maori language funding practices, setting up Maori language proficiency courses, discontinuing Te Ata Kura secondary teacher training and revising EFTS cost categories for teacher training in immersion Maori language programmes.

Strategy Two proposed to "redirect teacher support services to Maori immersion environments." Support services affected will include Maori advisers and resource teachers of Maori.

Strategy Three proposed new policy initiatives that include establishing a Maori Education Development Unit, a Maori Language Institute, paying an allowance to teachers in total immersion programmes, teacher training for unemployed people who are speakers of Maori, improved staffing ratios for total immersion classes, improved review and audit procedures particularly suited to Maori language education.

During 1992 it was announced that Te Atakura teacher training would be discontinued with funds being used to provide te reo proficiency inservice training. It was also announced that $\$ 1$ million would be targeted to train teachers for immersion programmes.

So far the "bold strategy" is neither "bold" nor "strategic".

\section{Comprehensive policy}

In February 1992, Cabinet directed officials to develop by the end of April 1992 "a coherent, overarching policy proposal for the implementation of measures, primarily within the education system (building on the Ministry of Education's work in developing a Ten Point Plan for Maori education) - but also outside it - to improve Maori education outcomes".

A draft dated 28 April 1992 made recommendations about government policy and outcomes, Maori language and Maori education, Kura Kaupapa Maori, teacher education, school charters, review and evaluation, the School Trustees' Association, good models of education, the school curriculum, examinations, failure-free compulsory education, tertiary education and whanau involvement in education.

Without a coherent policy, Maori education will continue to develop in an ad hoc way and at the whim of the market place where it is generally accorded low status when funds are allocated. To date there has been no public disclosure by government of a coherent policy that 
outlines "measures to make the education system more relevant and responsive to Maori needs".

\section{Inquiry into Maori education}

In January 1992 the Maori Affairs Select Committee initiated a government inquiry into Maori education. The inquiry will culminate in "a report to the House with such recommendations as the committee sees fit on changes to current and new policies."

The committee consulted widely during 1992 and submissions are still to be heard early in 1993. This is the second Maori Affairs Select Committee inquiry into Maori education since 1989.

\section{General}

Clearly, 1992 was a busy year for government in Maori education. However being busy does not always equate with being effective.

The benefits of government policy for Maori education are not being seen by schools.

In her report on Maori education to Te Reo Areare, Kaihautu Tiahuia Kawe-Small reflected on government's contribution to Maori education in 1992 as follows:

As far as we who work in classrooms are concerned, in 1992, government's waka o te Matauranga Maori has stranded up a creek without a paddle. We still don't have enough trained Maori-speaking teachers, teachers working in Maori education need more inservice training, we need more resources printed in Maori, our staffing ratios are too high and we need more support and advisory staff

Tamariki in Maori-medium education are entitled to better government support than they are getting now.

\section{NZEI's Miro Maori Developments}

\section{He aha te mea nui o te ao?}

Maku e ki atu ....

He tangata! He tangata! He tangata!
The 1990 report to annual meeting on "The Future of the Institute:Miro Heretanga" recommended that section 1.8 .3 of the Rules be:

The Institute shall give honour and effect to the Treaty of Waitangi with Maori and Tauiwi being equal parties in Institute operations.

This rule which was unanimously agreed to effectively put in motion the Miro Maori development plan which involved establishing:
Nga Aronui Tomua .from 1991
Te Reo Areare during 1992
Te Hui-a-Tau .in 1992

The development plan also stated that the Miro Maori will:

(a) represent Maori issues and Maori members in Institute operations;

(b) make decisions about Maori issues;

(c) mobilise Maori member involvement in Institute operations;

(d) select those who will represent Maoridom on Institute business;

(e) promote understanding of Maori needs and aspirations;

(f) be one of the parties that will aid the development of a bicultural Institute and education system;

(g) take responsibility for the development and mobilisation of NZEI Maori education policy.

The priorities for 1992 onwards will be to develop and establish links between existing structures and the Miro Maori, and redistribute resources so that both parties in the partnership can be effective.

The Miro Heretangata report proposed that the partnership structures in Figure 1 would help "the Institute to apply tikanga Maori practices, philosophies, principles and policies and truly reflect bicultural intentions." 


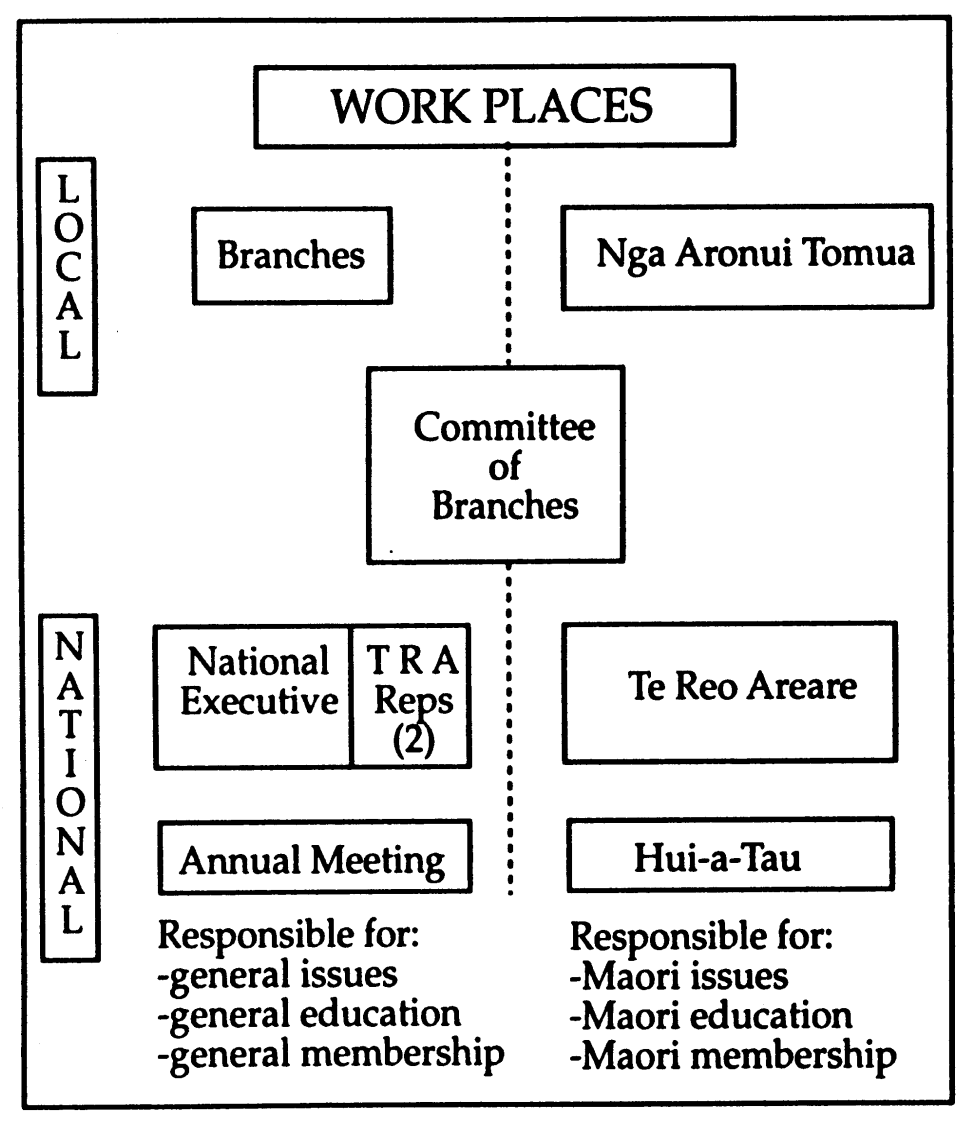

Figure 1 NZEI Treaty-Based Structures

\section{Nga Aronui Tomua}

Aronui Tomua have the same powers as NZEI branches. They are formed at local, district or regional levels with their boundaries and membership determined by members at that level. They differ from branches in that they only require a membership of 15 - compared with 25 for a branch - and they are funded at a slightly preferential rate.

The first Aronui Tomua - Turanga and Manawatu - were established in November following the 1990 annual meeting. By December 1992 the following 20 Aronui Tomua were in place:

$\begin{array}{ll}\text { Taitokerau } & \text { Napier } \\ \text { Tamaki Makaurau (2) } & \text { Hastings } \\ \text { Waikato } & \text { Taranaki } \\ \text { Tokoroa } & \text { Whanganui } \\ \text { Tauranga } & \text { Manawatu } \\ \text { Opotiki } & \text { Whanganui-a-Tara (2) } \\ \text { Rotorua } & \text { Blenheim } \\ \text { East Coast } & \text { Otautahi } \\ \text { Turanga } & \text { Murihiku }\end{array}$

Te Reo Areare

Te Reo Areare has similar rights and responsibilities to those of national executive. Its main role is to be accountable to members for the advancement of NZEI Maori education policy.

An interim Te Reo Areare represented by eight rohe and three Maori national executive members met for the first time on 23 March at Tapu Te Ranga Marae, Island Bay. That hui developed ideas about how decisions are to be made about Maori issues in NZEI and it developed guidelines about the future role of Te Reo Areare.

These developments continued when Te Reo Areare met at Tutahi Tonu Marae Tamaki Makaurau on 16 April, again at Tapu Te Ranga, 1011 May and at Education House, 13-14 July.

These meetings focused on preparing reports to the Hui-a-Tau that:

- identified key issues in Maori education and proposed strategies for moving forward; and

- clarified the roles and functions of the Miro Maori structure with particular emphasis on Te Reo Areare.

A feature of the report on the role of Te Reo Areare was that their key function is to be co-ordination. The decision-making and policy development roles were to remain in the forums that are readily accessible to the flax-root membership, i.e., Aronui Tomua and Hui-a-Tau.

The inaugural Te Reo Areare was established following the Hui-a-Tau.

Te Reo Areare now consists of twelve rohe representatives. Leadership is shared by a triumvirate of kaihautu representing their 
rohe. One rohe will be replaced each year in order to enable each rohe to be represented in the shared kaihautu role.

Te Reo Areare hui are open with all participants having equal rights to participate in the decision-making process.

Te Reo Areare is represented as of right on the national executive and meets formally with national executive to work through issues of common interest.

\section{Hui-a-Tau}

The first hui to call together representatives of nga Aronui Tomua was held at Rongopai Marae, Patutahi from 27-29 January 1992.

This hui established the interim Te Reo Areare and put in place the 1992 work programme for Maori education. The inaugural Hui-a-Tau was held at Tauwhara Marae, Taitokerau from 14-16 August, 1992.

That hui established Te Reo Areare and set guidelines for further developments (e.g., amalgamation, kaumatua, annual meeting, links with iwi). It also gave Maori names to some features of NZEI and set Maori education priorities for 1992/93.

More than 100 people, including a delegation from as far away as Murihiku, attended the hui.

The 1993 Hui-a-Tau is to be held at Parakino, from 23-25 July.

\section{Honohonotanga}

During 1992 links between Maori and the general structures were strengthened.

At the locallevel, many Aronui Tomua and branches have reciprocal rights at each others meetings. At the regional level, Aronui Tomua are represented as of right on Committees of Branches (COBs) and many have policies that ensure Maori are represented on their standing committees and working parties.

At the national level, Te Reo Areare is represented on national executive and on all NZEI working parties, task forces and delegations. Maori selection processes are used.

In addition, Aronui Tomua participate in annual meeting with the same status as branch representatives. A rule change has been drafted for 1993 to ensure that Te Reo Areare representatives attend with the same status as National Executive members.
Decisions made by the Maori structures form NZEI policy on Maori education. They are received and discussed by the general membership but are not able to be amended by them.

Regular meetings between the two groups ensure that there is a forum for resolving conflicts of interest should they occur.

In his speech to the World Council of Teaching Professionals (WCOTP) Conference in Stockholm, 21-26 January 1993, Te Reo Areare representative Hone Mutu said: "Our union partnership is based on rights and responsibilities. Both parties have the right to make decisions and the responsibility to support each other's goals and aspirations."

\section{Maori Education Developments}

Maori education has been a priority for NZEI in recent times. The 1982 report to annual meeting, Te Tatai Hono, established policies that NZEI members have negotiated with some success into the education system.

Since 1985 annual meeting has received reports on progress in Maori education. The reports have had the dual functions of reporting on what has happened and foreshadowing issues for the future.

The most significant piece of work done by NZEI in 1992 in Maori education was the March production of "Te Katete Korite".

In its introduction, Te Katete Korite is described as a paper that presents a coordinated proposal for Maori education. It:

- provides a definition of Maori education

- develops a relationship between the national curriculum and the Maori curriculum

- traces the growth of Maori initiatives in education

- traces the non-growth of resources

- expresses NZEI priorities for Maori education

- looks at immediate initiatives necessary at both national and community levels.

It is a genuine proposal to evaluate the present situation and provide a direction for future Maori education developments. Government policies for Maori education are developed in a very ad hoc way. As crises emerge, reactive policies are created. 
The outcomes have in many ways produced ineffective programmes, disenchantment and the inefficient use of resources.

Te Katete Korite was distributed to all schools, organisations involved in Maori education including government departments and to Maori communities.

In Te Katete Korite, NZEI has identified four goals that need to be addressed if Maori education is to move forward:

\section{Tino Rangatiratanga}

The aim is to re-establish Maori authority over Maori education policies and the resources that are needed to provide equitable outcomes in education.

\section{Te Reo Me Ona Tikanga Maori}

The aim is to implement programmes that will promote, maintain and re-vitalise te reo me ona tikanga Maori in

Aotearoa communities.

\section{Maori Achievement}

The aim is for Maori people to have the same success in education and society as other people. The focus must be on outcomes not just opportunities.

\section{Partnership}

The aim is to share resources, responsibility and authority in a way that accords mutual respect and meaning to working together towards the common goal of educational achievement.

The NZEIMaori education priorities for 1992/93 were decided by Hui-aTau and endorsed by annual meeting. They are:

a) professional development for teachers in bilingual and immersion education;

b) that all preservice teacher training programmes require all trainees to graduate as competent speakers of Maori;

c) a substantial increase in the quality and quantity of material resources to support learning in te reo Maori; d) the enhancement of a centrally funded Maori education support service (advisers, Resource Teachers of Maori (RTMs), kaiarahi reo).

There were a number of significant Maori education developments in the primary education system in 1993. The growth in the numbers of bilingual and immersion programmes and Kura Kaupapa Maori, the development of positive attitudes towards Maori education by teachers and communities and the increased whanau participation at all levels of school activities have occurred because teachers and parents at the flax roots have instigated the changes. NZEI's goals and priorities aim to give primary schools the support they need to deliver quality education.

$$
\begin{aligned}
& \text { Whakamanatia } \\
& \text { a tatou tamariki } \\
& \text { o tatou kura } \\
& \text { me te iwi whanui }
\end{aligned}
$$

\section{General Education}

The main object of NZEI is to "advance the cause of education generally while upholding and maintaining the just claims of its members individually and collectively."

In 1992 NZEI campaigned vigorously to protect education as a public right and service and to enhance national standards and the delivery of quality education by focusing on key areas such as teacher registration, staffing entitlements, bulk funding, special education, advisory services, employment contracts, Maori education, curriculum developments, getting best value from public funds and amalgamation.

All activities involved Maori participation. The type of participation can best be illustrated by focusing on aspects of the bulk funding and employment contracts activities.

\section{Bulk funding}

In July 1992 NZEI and Combined Early Childhood Union of Aotearoa (CECUA) launched a project "Te Putea Maminga" that provided educators and the public with an analysis of the impact of bulk funding 
of teachers' salaries on Maori education. In an attempt to lure Maori communities into the bulk funding trial, Ministry of Education officials have attempted to market it as the realisation of Tino Rangatiratanga.

The publication written by NZEI members Laures Park and Mere Clarke refutes that rhetoric and states that "bulk funding will strengthen government control over Maori education."

The booklet outlines why bulk funding is an issue for Maori people, reports on what Maori educators have said, looks at the features of the bulk funding experience in early childhood education in NZ's past history and in the United Kingdom.

Finally, it comments on the issues as they relate to Maori education. The booklet is supported by a leaflet and poster that focus on the key messages. This project enhanced the union fight against the imposition of bulk funding on schools and is part of the total NZEI resource to continue opposing bulk funding.

\section{Employment contracts}

The 1992 contract round was arduous and at times hostile. In preparation for negotiations NZEI identified Maori education as one of the areas that should be enhanced by providing for appropriate pay and conditions in the new contract.

The four issues that were bargained for were:

- an enhancement of redeployment provisions when schools are redesignated as Kura Kaupapa Maori;

- improved staffing for classes with immersion and bilingual programmes;

- centrally funded leave for inservice for teachers in immersion education; and

- remuneration for teachers who have competency in te reo Maori.

The only actual gain for Maori education in the contract was for the redeployment proposals. However, the statement of the parties which formed part of the settlement of the contract requires NZEI, MOE and SSC to consult regularly at a senior level to promote progress in Maori education.

In commenting to Te Reo Areare on Maori participation in the general education issues of NZEI, Kaihautu Amber Udy said, "Our first priority will always be to achieve what we want in Maori education. I don't really mind who is aboard te waka o te matauranga Maori. The more kai-hoe we have, the better. My real concern is that Maori must decide where the waka is going. I believe our structures enable that to happen and also present us with opportunities to steer general education in the direction of providing bilingual and bicultural education for all learners."

\section{Conclusion}

NZEI's recent developments in Maori education and Maori issues are the realisation of the dreams of many Maori teachers. The developments are also the ray of hope for young Maori entering the education system.

The developments have focused on structures to empower Maori to make decisions and requiring the NZEI to providing sufficient resources and energy to implement and support the decisions.

What the plans and words don't state is the amount of goodwill, trust and honesty that is needed to make it happen.

Unions have the power to mobilise people - and that can be most effective when all of the people can be empowered.

The politicisation of Maori in the education system can happen, is happening. During 1992 NZEI helped the process along its way.

$$
\begin{aligned}
& \text { He moana pukepuke } \\
& \text { e ekangia e te waka }
\end{aligned}
$$

\section{References}

AGB McNair, Survey of Demand for Bilingual and Immersion Education in Maori, Report to the Ministry of Education, 1992.

Dunn, Alastair et al., The Education Sector Workforce, A Report on the Education Services Census, 1999

Ministry of Education, Draft of Paper to Officials, 18 April 1992.

Ministry of Education, Maori Language and Maori, Draft No. 5 of Report to Ministers Maori Development and Education.

National Maori Congress, Te Ripoata A Te Roopu Whakapumau A Te Whakakotahitanga, 1992. 
NZEI Publications:

Future of the Institute, Report to Annual Meeting 1990.

Moving Forward, Reports to Annual Meeting 1991, 1992.

Progress in Maori Education, Reports to Annual Meeting 1991, 1992.

Report on NZEI Hui-a-Tau, 1992.

Te Katete Korite, 1992.

Te Putea Maminga, 1992

\section{The author}

Bill Hamilton, of Ngati Kahungunu, Ngati Raukawa and Nga Rauru descent,

is NZEI Matua Takawaenga with responsibility for Maori education and

Maori issues. He has worked in primary education for more than twenty

years having been a classroom teacher, principal and Maori Education

Advisor. 